\title{
Role of Subcellular Remodeling in Cardiac Dysfunction due to Congestive Heart Failure
}

\author{
Andrea P. Babick Naranjan S. Dhalla \\ Institute of Cardiovascular Sciences, St. Boniface General Hospital Research Center and Department of Physiology, \\ Faculty of Medicine, University of Manitoba, Winnipeg, Canada
}

\section{Key Words}

Myocardial infarction - Pressure overload · Volume overload · Cardiac hypertrophy · Cardiac gene expression

\begin{abstract}
Although alterations in the size and shape of the heart (cardiac remodeling) are considered in explaining cardiac dysfunction during the development of congestive heart failure $(\mathrm{CHF})$, there are several conditions including initial stages of cardiac hypertrophy, where cardiac remodeling has also been found to be associated with either an increased or no change in heart function. Extensive studies have indicated that cardiac dysfunction is related to defects in one or more subcellular organelles such as myofibrils, sarcoplasmic reticulum and sarcolemma, depending upon the stage of CHF. Such subcellular abnormalities in the failing hearts have been shown to occur at both genetic and protein levels. Blockade of the renin-angiotensin system has been reported to partially attenuate changes in subcellular protein, gene expression, functional activities and cardiac performance in CHF. These observations provide support for the role of subcellular remodeling (alterations in molecular and biochemical composition of subcellular organelles) in cardiac dysfunction in the failing heart. On the basis of existing knowledge, it appears that subcellular remodeling during the process of cardiac remodeling plays a major role in the development of cardiac dysfunction in CHF.
\end{abstract}

Copyright $\odot 2007$ S. Karger AG, Basel
(C) 2007 S. Karger AG, Basel

$1011-7571 / 07 / 0162-0081 \$ 23.50 / 0$

Fax +4161306 1234

E-Mail karger@karger.ch

www.karger.com
Accessible online at:

www.karger.com/mpp

\section{Introduction}

Through decades of continuous research, along with the constant rise in the number of patients with failing hearts, congestive heart failure (CHF) is presently considered as a complex progressive disease and not just a single isolated syndrome [1]. The inability of the heart to pump sufficient blood, to maintain a balanced oxygen supply and demand relationship in the human body at both rest and exercise, is the hallmark feature of CHF. Particularly, CHF is associated with an overload of fluid, which drowns peripheral organs such as liver, kidneys, lungs, skeletal muscle as well as the heart, whereby the examination of the etiologies of CHF has become an area of intensive interest [2]. It is noteworthy that CHF is the common concluding pathway for a majority of primary cardiovascular diseases including hypertension, coronary atherosclerosis, cardiomyopathy, diabetes, myocarditis and congenital heart malformations $[2,3]$. The lifetime risk of developing CHF is 1 in 5, where the long-term survival is relatively poor; up to one third of those diagnosed with CHF die within the first 12 months, whereas half of the patients survive the 5-year mark [3]. It has also been reported that CHF currently affects more than 5 million Americans and is responsible for more than 700,000 deaths per year, costing the American economy USD 50 billion annually [4]. In fact, CHF has become a concern of epidemic proportion worldwide. Since the progression of CHF emerges as a widespread and coordi- 
nated reaction to cardiac insult, giving a complex cascade of events that underlie changes in the failing myocardi$\mathrm{um}$, this review is focused on discussion regarding the mechanisms which have been proposed to explain heart dysfunction in CHF under chronic conditions.

\section{Cardiac Remodeling and CHF}

CHF is invariably preceded by cardiac hypertrophy, which occurs due to a wide variety of mechanisms [5-8]. Cardiac myocyte hypertrophy is initiated in response to mechanical alterations such as hemodynamic overload, pressure overload and volume overload, although various cytokines and hormones are considered to be involved in this process. An increase in mechanical load also occurs when the heart experiences an ischemic insult and the contractile elements of the myocardium are lost or rendered dysfunctional [2]. Hypertrophy is most probably intended to promote efficient pumping by intensifying the number of cardiac contractile units, while concomitantly decreasing the amount of wall stress by augmenting the wall thickness of the myocardium $[2,9]$. Immediately following an ischemic episode such as myocardial infarction (MI), there is an acute loss of myocardial cells that leads to fibrosis, scar formation as well as uncharacteristic loading conditions, which results in dilatation of the ventricular chamber with a transformation in shape and size [10]. This reconstruction of the heart (cardiac remodeling) is usually associated with deleterious function of the heart as a pump [10]. It is believed that the progression of chamber enlargement following MI is directly related to three factors: the healing of the infarct, the size of the infarct, and the wall stress imposed on the ventricle. Although MI is a major cause of cardiac remodeling and $\mathrm{CHF}$, cardiac remodeling has been observed to be associated with other types of CHF. In fact, the phenomenon of cardiac remodeling is now a well established feature in the progression of cardiovascular disease and is currently prevailing as an important therapeutic target in the failing heart [10]. Cardiac remodeling is generally characterized by changes in gene expression, molecular mechanisms and cellular structures which are clinically evident as a result of alterations in cardiac size, shape and function after ischemic injury to the heart, as well as due to pressure overload and volume overload [9, 11-17]. MI invariably leads to infarct expansion, which can be defined as 'acute dilation and thinning of the area of infarction not explained by additional myocardial necrosis' [18]. The expansion of the infarct can be observed prior to, and during the stage of necrotic tissue resorption, yet before the massive deposition of collagen [19]. Hence, infarct expansion is a model example of coupling amongst global changes in ventricular configuration and the principal cellular adaptations [20].

Although the mechanisms responsible for the transition of cardiac hypertrophy to heart failure have not yet been fully elucidated, cardiac remodeling as a result of marked alterations in the extracellular matrix has been proposed to be closely associated with the advancement of CHF [21-23]. Key indications to support this view can be found in the extracellular space of the myocardium, which is home to a wide variety of cells that are structurally and functionally unique. Unlike the cardiomyocytes that comprise one third of the cell population in the heart, endothelial cells, vascular smooth muscle cells, cardiac fibroblasts and macrophages reside in the cardiac interstitium and are collectively termed as nonmyocyte cells [21]. The growth of nonmyocyte cells is referred to as interstitial structural remodeling, whereby an accumulation of collagen is observed. Due to the fact that nonmyocyte and myocyte growth are independent of each other, hypertrophy of the myocardium occurs as a homogeneous or heterogeneous process that is a result of proportionate or disproportionate nonmyocyte growth, respectively [24]. Fibroblasts, which comprise $>90 \%$ of the nonmyocyte cells, enhance the production of collagen, in response to injury such as MI, and are one of the key elements in cardiac remodeling that leads to cardiac dysfunction $[25,26]$. Review of the literature has revealed that during the transition to CHF, the stiffness of the heart is most probably attributed to extreme collagen deposition, thereby disrupting normal pumping capacity and further contributing to arrhythmogenicity in its progression to sudden cardiac death [25]. During this structural remodeling of the heart, the compilation of fibrous tissue enhances the occurrence of detrimental cardiovascular effects of ventricular dysfunction and arrhythmias [27]. In addition to the alterations observed exterior to the cardiomyocyte, changes in the sarcoplasmic reticulum (SR) and sarcolemma (SL), which modulate the intracellular concentration of free $\mathrm{Ca}^{2+}$ and regulate the contractile apparatus in cardiomyocytes [28], have been identified in the failing heart in conjunction with alterations in the sensitivity of the myofibrils (MF) to $\mathrm{Ca}^{2+}[28-31]$. Such observations indicating the role of defects in SL, SR and MF in cardiac dysfunction do not rule out the contribution of changes in the extracellular matrix to cardiac remodeling, but rather incorporate all systems into one network that complement each other in the progression into $\mathrm{CHF}$. 


\section{Subcellular Abnormalities in the Failing Heart}

Despite the existence of a large amount of information concerning alterations in subcellular organelles in cardiac hypertrophy leading to heart failure, it is apparent that the mechanisms of subcellular remodeling remain poorly understood. In view of the fact that regulation of $\mathrm{Ca}^{2+}$ flow in and out of the cardiomyocyte is dependent upon the SL and the SR for efficient contraction and relaxation, there is a large interest concerning the abnormalities in the function of these specific cardiac membrane networks in CHF [31]. During the excitation-contraction process, a small amount of $\mathrm{Ca}^{2+}$ entering through SL releases a large amount of $\mathrm{Ca}^{2+}$ from the SR stores for the occurrence of cardiac contraction. On the other hand, for cardiac relaxation, approximately $80 \%$ of the $\mathrm{Ca}^{2+}$ transport throughout the cell occurs via the $\mathrm{SR}$, while the residual $20 \%$ is transferred via the $\mathrm{Na}^{+} / \mathrm{Ca}^{2+}$ exchange and the $\mathrm{Ca}^{2+}$ pump located in the SL [28]. Moreover, as a result of this coordinated performance of these cardiac membrane systems in controlling $\mathrm{Ca}^{2+}$ transport in parallel with heart function, it has been suggested that cardiac dysfunction is a consequence of remodeling of both the SL and SR membranes [31]. In particular, loss of $\mathrm{Ca}^{2+}$ homeostasis has been observed in a diverse spectrum of heart maladies that include cardiac hypertrophy due to pressure overload, primary idiopathic cardiomyopathy and various etiologies that contribute to overall CHF [32, 33].

\section{Modifications in the Expression of Sarcolemmal $\mathrm{Na}^{+}-\mathrm{K}^{+}$ATPase}

A prominent member of the SL proteins that was discovered in 1957 by Jens Christian Skou is the $\mathrm{Na}^{+}-\mathrm{K}^{+}$adenosine triphosphatase $\left(\mathrm{Na}^{+}-\mathrm{K}^{+}\right.$ATPase), which exists in virtually all animal tissues, as well as the human myocardium [34]. This enzyme is responsible for the active transport of $3 \mathrm{Na}^{+}$ions out of the cell, while simultaneously importing $2 \mathrm{~K}^{+}$ions. Hence, the $\mathrm{Na}^{+}-\mathrm{K}^{+}$ATPase functions to maintain cell volume, establish ionic gradients and preserve membrane potentials of the cardiomyocyte [35]. Consequently, defects in the function of this enzyme were found to be related to abnormalities in cardiac performance and have been outlined as a salient feature of the subcellular basis of CHF [36, 37].

The $\mathrm{Na}^{+}-\mathrm{K}^{+}$ATPase is composed of different subunits such as $\alpha_{1}, \alpha_{2}, \alpha_{3}, \beta_{1}, \beta_{2}$, and $\beta_{3}$, and consequently several investigators have examined each subunit individually. Charlemagne et al. [36] reported that in mild and severe stages of hypertrophy, there was a reduction in the $\alpha_{2}$ mRNA and protein levels, while the compensated stage of hypertrophy revealed no alterations in the $\alpha_{1}$ and $\beta_{1}$ mRNA and protein levels. Furthermore, the $\alpha_{3}$ mRNA and protein levels were increased at 5 days and 30-50 days post-stenosis of the abdominal aorta, respectively. Another study by Semb et al. [38] reported that 6 weeks post-MI showed a reduction in $\alpha_{2}$ mRNA and protein levels, with no alterations in the expression of the $\alpha_{1}$ and $\beta_{1}$ subunits, but an increase in the $\alpha_{3}$ subunit at the transcriptional level. This was supported by Book et al. [39], who reported that at 8 weeks post-stenosis of the left renal artery, there was a decrease in the $\alpha_{2}$ mRNA and protein levels with unchanged $\alpha_{1}$ expression, and a reduction in the $\beta_{1}$ protein levels. A unique experimental animal models known as the UM-X7.1 cardiomyopathic hamster was studied by Kato et al. [40], who reported a decrease in the $\alpha_{2}$ mRNA, protein and $\alpha_{3}$ protein levels with enhanced $\alpha_{1}$ and $\beta_{1}$ mRNA and protein levels, with contrasting undetected levels of $\alpha_{3}$ mRNA.

In terms of the functional alterations in the $\mathrm{Na}^{+}-\mathrm{K}^{+}$ ATPase, Dixon et al. [37] monitored its activity at 4, 8, and 16 weeks post-MI, and discovered that at 4 weeks, the activity was unchanged, but at 8 and 16 weeks the activity was significantly decreased. This finding suggested that the activity of the $\mathrm{Na}^{+}-\mathrm{K}^{+}$ATPase may conceivably play a part in the adaptive mechanism of the heart that occurs during the development of CHF. Auxiliary studies by Shao et al. [41] demonstrated that reduced activity of this SL enzyme was coupled with the reduction in the expression of the $\alpha_{1}, \alpha_{2}$, and $\beta_{1}$ mRNA and protein levels, in addition to an elevation in the expression of the $\alpha_{3}$ subunit. Shao et al. [41] further concluded that when imidapril (an angiotensin-converting enzyme inhibitor) treatment was administered, the $\mathrm{Na}^{+}-\mathrm{K}^{+}$ATPase activity improved and the changes in the gene expression of the SL proteins were attenuated as a consequence of the blockade of the renin-angiotensin system (RAS) in CHF. A more extensive study by Ren et al. [42] revealed that a 37 -week treatment with imidapril, 3 weeks post-MI, attenuated the reduction in the activity of the $\mathrm{Na}^{+}-\mathrm{K}^{+}$ ATPase, with paralleled trends in the expression of both the $\mathrm{Na}^{+}-\mathrm{K}^{+}$ATPase and $\mathrm{Na}^{+}-\mathrm{Ca}^{2+}$ ATPase exchanger.

\section{Modifications in the Expression of Sarcolemmal \\ $\mathrm{Na}^{+}-\mathrm{Ca}^{2+}$ Exchanger}

The $\mathrm{Na}^{+}-\mathrm{Ca}^{2+}$ exchange protein, which uses the influx of $\mathrm{Na}^{+}$to extrude intracellular $\mathrm{Ca}^{2+}$, is a prominent member of the SL proteins and is situated in the T-tubules closest to the sites of $\mathrm{Ca}^{2+}$ release from the SR. The fully mature form of the $\mathrm{Na}^{+}-\mathrm{Ca}^{2+}$ exchanger exists as $120 \mathrm{kDa}$ 
and is responsible for maintaining $\mathrm{Ca}^{2+}$ homeostasis in the cell [43]. Since its discovery over 30 years ago, the kinetic parameters of this protein suggest that this system can encompass rapid $\mathrm{Ca}^{2+}$ transport in and out of the myocardial cell during the cardiac contractile cycle. In a clinical study relating dilated cardiomyopathy and coronary artery disease, Studer et al. [44] evaluated the expression of the $\mathrm{Na}^{+}-\mathrm{Ca}^{2+}$ exchanger together with the SR $\mathrm{Ca}^{2+}$ ATPase (SERCA). Amongst the two patient groups employed, the mRNA and protein levels of the $\mathrm{Na}^{+}-\mathrm{Ca}^{2+}$ exchanger were elevated in contrast to the reduction in the mRNA and protein levels of SERCA [44]; this observation gave rise to the idea that the increased expression of the $\mathrm{Na}^{+}-\mathrm{Ca}^{2+}$ exchanger somewhat compensated for the diminished function of the SR to remove $\mathrm{Ca}^{2+}$ from the cytosol during relaxation. Furthermore, these findings supplemented by Hasenfuss et al. [45] have affirmed that the decreased levels of SERCA, in concert with unaltered levels of the $\mathrm{Na}^{+}-\mathrm{Ca}^{2+}$ exchanger, accounted for the disorder in diastolic dysfunction. On the other hand, early stages of CHF due to MI have shown a reduction in the activity, mRNA and protein expression of $\mathrm{Na}^{+}-\mathrm{Ca}^{2+}$ exchanger [41, 46]. Schillinger et al. [47] illustrated, in the hours preceding cardiac transplantation, that the increase in the $\mathrm{Na}^{+}-\mathrm{Ca}^{2+}$ exchange, collectively with the reduction in SERCA, provided a substantial association amongst neurohormonal levels of epinephrine and SL activity of the $\mathrm{Na}^{+}-\mathrm{Ca}^{2+}$ exchanger. They further projected that during $\mathrm{CHF}$, the activation of the sympathetic nervous system (SNS) conceivably amplified the expression of the $\mathrm{Na}^{+}-\mathrm{Ca}^{2+}$ exchanger, which may have potentially had a role in the onset of malignant ventricular arrhythmias. The intensifying concern of progressing arrhythmias in CHF was previously examined by Reinecke et al. [48], who observed that the enhanced activity of the $\mathrm{Na}^{+}-$ $\mathrm{Ca}^{2+}$ exchange in end-stage CHF was a result of its increased protein levels. In addition, this increase provided an augmented influx of $\mathrm{Na}^{+}$, which was further associated with potential membrane depolarizations to create amplified arrhythmogenesis if the $\mathrm{Na}^{+}-\mathrm{Ca}^{2+}$ sustained movement predominantly in the forward mode.

\section{Alterations in the Expression of SR $\mathrm{Ca}^{2+}{ }_{-}$Pump}

\section{ATPase}

During cardiac relaxation, $\mathrm{Ca}^{2+}$ is pumped from the cytosol into the SR through the $105-\mathrm{kDa}$ SR $\mathrm{Ca}^{2+}$-pump ATPase [49]. As this enzyme is responsible for the diastolic phase of the cardiac cycle, any impairments in this process of $\mathrm{Ca}^{2+}$ sequestration could possibly contribute to the pathophysiology of cardiac dysfunction in CHF.
Supporting evidence for this postulation regarding cardiac dysfunction in the failing heart include an abnormal force-frequency relationship, whereby increased frequency of stimulation gives a decreased developed tension [50]. Clinical studies performed on the failing human myocardium have shown an overall decrease in SERCA mRNA [51-53] and protein levels [54, 55], in addition to a reduction in the abnormal handling of $\mathrm{Ca}^{2+}$ by SERCA itself $[56,57]$. To assess the validity of these applications, different investigators have attempted to compare the findings in animal models of $\mathrm{CHF}$ with the failing human myocardium. Most of the results have shown to be controversial, yet some unanimity has surfaced. In a report by Movsesian and Schwinger [58], there are findings that show a reduction in the $\mathrm{Ca}^{2+}$ sequestration of the failing human myocardium; this is consistent with those of the animal models and can be attributed to decreased levels of SERCA mRNA. Further studies supporting this decrease in SERCA expression and function in the failing heart were carried out in experimental models of the pressure-overloaded rat [49], the tachycardia-induced mongrel dog [59], the volume-overloaded rat [60], infarcted rats [61] and the transgenically engineered hypertensive rat [62]. Though this offers insight into the molecular basis for the pathogenesis of CHF, the data that is accumulated raises more questions than that which have been answered. If in fact the protein level of SERCA remains unchanged in the failing heart, the answer may possibly lie in the complex mechanisms concerning transcription, translation and protein degradation as an entire cumulative process [58].

Alterations in the Expression of Sarcoplasmic

Reticular Phospholamban Protein (PLB)

The SR $\mathrm{Ca}^{2+}$ uptake is intimately regulated by a SR protein, PLB. Composed of five equal monomers, this $30-\mathrm{kDa}$ protein inhibits the activity of SERCA through direct interaction and depresses the transport of $\mathrm{Ca}^{2+}$ into the SR [63]. Compelling evidence to substantiate this phenomenon was seen in mice deficient in the PLB gene in comparison to their control [64]; this study demonstrated that the PLB-deficient mice exhibited high rates of contraction and relaxation in the absence of isoproterenol, but showed no increase in response in the presence of isoproterenol, which correlated well with the fact that the control mice had low rates of contraction and relaxation. Since both the gene expression and protein content of PLB were decreased in the failing heart due to MI [61], it appears that this change is an adaptive mechanism to support SR function in the failing heart. 
Alterations in the Expression of SR Ryanodine

Receptor

$\mathrm{Ca}^{2+}$ release from the SR is achieved through the ryanodine receptor (RyR), which is composed of four monomers of $\sim 560,000 \mathrm{kDa}$. A decrease in $\mathrm{SR} \mathrm{Ca}^{2+}$ release channel activity was observed in ischemic cardiomyopathy as well as in hearts failing due to valvular disease [65]. In studies comparing the $\mathrm{Ca}^{2+}$ release activity in both pressure-overloaded and volume-overloaded rats, Hisamatsu et al. [60] have shown enhanced $\mathrm{Ca}^{2+}$ release in the left ventricular hypertrophy due to pressure overload, with a contrasting decrease in $\mathrm{Ca}^{2+}$ release activity and number of RyR in the volume-overloaded model. Cory et al. [66] have observed that both the density of the SR terminal cisternae and the activity of RyR were reduced in the Doberman pinscher dog model of CHF, as well as during rapid ventricular pacing in mongrel dogs. Additionally, Arai et al. [53] documented a reduction in RyR mRNA in patients suffering from end-stage CHF from primary pulmonary hypertension, or ischemic heart disease. The SR $\mathrm{Ca}^{2+}$ release activity, RyR protein content and RyR gene expression were depressed in hearts failing due to MI [61].

\section{Remodeling of the MF Proteins}

The structural contractile unit of the myocardium controls the transition of the diastolic state to the activated state through various intricate steric, allosteric and cooperative mechanisms of the myofibrillar thick and thin filaments. Various studies have revealed a significant reduction in MF ATPase in the failing heart, including $\mathrm{CHF}$ due to mitral valve insufficiency, pressure overload, idiopathic cardiomyopathy, ischemic heart disease and coronary artery disease [67-71]. Of particular importance, there are two genes located in tandem on chromosome 14 that encode the cardiac myosin heavy chain (MHC), and are termed $\alpha-\mathrm{MHC}$ and $\beta-\mathrm{MHC}$. Given that the $\alpha$-MHC isoform results in a high-power, low-economy ATPase activity, whereas the $\beta$-MHC isoform gives rise to a low-power, high-economy ATPase myofilament activity, the events associated with cardiac stress promote a shift in expression toward the $\beta$-MHC for a more efficient performance $[72,73]$. Eble et al. [74] conducted a molecular study in the failing hearts of rabbits and reported an increase in the MHC synthesis in left ventricular dysfunction due to chronic ventricular tachycardia that could be explained by an increased MHC translational efficiency. This response was further supported by Imamura et al. [75], who reported an elevated synthesis in MHC in dogs subjected to pressure overload. Further- more, in the rat model of pressure-overload hypertrophy, Toffolo et al. [56] described an augmentation in cell size followed by a change in the expression of myosin, to produce the slow-migrating, economic $\mathrm{V}_{3}$ isoform, while exhibiting an increased number of MF units during the adaptive process of the myocardium. On the other hand, hearts failing due to MI showed depressed MF ATPase activity, a shift in myosin isozymes and corresponding changes in gene expression $[57,76]$.

\section{Mechanisms of Subcellular Remodeling in CHF}

From the foregoing discussion, it is evident that SL, SR, $\mathrm{MF}$ and extracellular matrix become altered in terms of chemical composition and molecular structure in CHF. However, the mechanisms of such subcellular remodeling are understood poorly. Since both SNS and RAS are activated in CHF $[2,7,10,77]$, it is likely that elevated levels of circulating levels of norepinephrine and angiotensin II (Ang II) may produce subcellular remodeling in the failing hearts. Notwithstanding the fact that the SNS offers a means of supporting cardiac contractile function, it has been documented that the failing human heart becomes less sensitive to stimulation of the SNS [78-82]. Overstimulation of the SNS is accompanied by different biochemical alterations including an increase in the expression of the $\alpha$-subunit of inhibitory $G$ proteins in the failing heart [83]. Furthermore, Lai et al. [84] have documented that norepinephrine infusion in dog hearts produced a decrease in the mRNA and protein levels of SERCA, which paralleled those hearts of pacing-induced CHF, with no change in the RyR, calsequestrin and PLB mRNA levels. It should be mentioned that RAS is also a critical entity in the regulation of cardiovascular function, as it plays a major role in the impairment of endothelial cell function, improvement of growth, progression of apoptosis, and the development of oxidative stress [77]. It has been shown by Ju et al. [85] that Ang II increased levels of mRNA for the sarcolemmal $\mathrm{Na}^{+}-\mathrm{Ca}^{2+}$ exchange, the SR ryanodine $\mathrm{Ca}^{2+}$ receptor, and the SR SERCA protein in cardiomyocytes. Rouet-Benzineb et al. [86] observed that the transcription factor NF- $\mathrm{KB}$ was translocated into the nucleus from the cytoplasm via the protein kinase $\mathrm{C}$ pathway in neonatal rat cardiomyocytes, which were subjected to Ang II stimulation and this process was blocked with the administration of calphostin C, a specific protein kinase $\mathrm{C}$ inhibitor.

Throughout years of research, extensive efforts have been made to improve heart function in the infarcted an- 
imals upon treatments with various pharmacological interventions. Certain therapies include angiotensin-converting enzyme inhibitors (ACEIs) and angiotensin receptor blockers [77]. In a long-term study focusing on the effects of the ACEI captopril on left ventricular remodeling of the myocardial infarcted canine model, Jugdutt et al. [87] revealed attenuation of early infarct expansion, the absence of late wall thinning, a reduction in diastolic bulging, and eradication of aneurysms, as well as a general restitution in overall cardiac systolic function. In another study involving ACEI treatment, McDonald et al. [88] discovered that during progressive ventricular remodeling in the myocardial infarcted rat, late captopril therapy attenuated further increase in cell length, which is associated with myocyte hypertrophy and growth of the cardiac interstitium due to MI. Furthermore, Dixon et al. [89] have observed that the administration of both the ACEI and Ang II type-1 receptor antagonist in infarcted rats showed an overall reduction in cardiac fibrosis and suggested that Ang II may be involved in the regulation of cardiac collagen synthesis after MI at the posttranscriptional site. Thus, these investigations have provided evidence that in addition to SNS, RAS is intimately involved in the pathogenesis of cardiac dysfunction in CHF.

Findings from basic research studies, compiled with discoveries from important clinical trials, have proven significant transformations in both the extent of treatments available and in the continuing development of the knowledge of mechanisms underlying CHF [90-92]. It is due to the efforts of different investigators that changes amongst the many organelle systems have been identified and thus far, have been formulated into new concepts of subcellular remodeling for the development of CHF [93]. Several investigators by employing cDNA microarrays, proteomics, and other molecular approaches have identified defects in signal transduction mechanisms during the progression of CHF [94-100]. Essentially, CHF is preventable predominantly through the control of hormonal disturbances and other various factors, and the past 15 years of multiple trials have reported a significant decline in mortality in patients suffering from CHF [90-93]. It is also critical to note that profound alterations in cardiac structure and function are heavily dependent on aging. It has been well established that aging is one of the prominent risk factors involved in the development of CHF [101]. As significant changes such as increased ventricular wall thickening, myocardial fibrosis and valvular fibro-calcification contribute to decreased ventricular compliance [102], it is evident that the path to CHF is in- evitably a major medical concern of the elderly. To support this notion, studies of advanced aging-associated CHF in the rat model by Pacher et al. [102] have characterized a decrease in systolic performance in association with prolonged relaxation that is accompanied by a rise in cardiac diastolic stiffness. While the significance of cardiac remodeling in CHF still remains to be elucidated, it is apparent that the cardiac subcellular organelles need to be selectively treated and appropriate therapy needs to be designed. It is therefore of greatest importance to acquire the underlying mechanisms involved as we are challenged to study the prevention of structural modification in the myocardium as well as changes in subcellular organelles using diverse approaches and experimental methodologies for inducing CHF [103-105]. In addition, it will be essential to carry out experiments showing the reversal of subcellular remodeling using a wide variety of pharmacological and surgical interventions.

\section{Acknowledgments}

This review was supported by a grant from the Canadian Institute of Health Research. Andrea Babick was supported by a Predoctoral Fellowship by the University of Manitoba. 


\section{References}

$>1$ Levy D, Kenchaiah S, Larson MG, Benjamin EJ, Kupka MJ, Ho KK, Murabito JM, Vasan RS: Long-term trends in the incidence of and survival with heart failure. N Engl J Med 2002;347:1397-1402.

$\checkmark 2$ Dhalla NS, Afzal N, Beamish RE, Naimark B, Takeda N, Nagano M: Pathophysiology of cardiac dysfunction in congestive heart failure. Can J Cardiol 1993;9:873-887.

$>3$ Lloyd-Jones DM, Larson MG, Leip EP, Beiser A, D’Agostino RB, Kannel WB, Murabito JM, Vasan RS, Benjamin EJ, Levy D: Lifetime risk for developing congestive heart failure: the Framingham Heart Study. Circulation 2002;106:3068-3072.

$\checkmark 4$ Zeltsman D, Acker MA: Surgical management of heart failure: an overview. Annu Rev Med 2002;53:383-391.

$>5$ Deten A, Volz H, Briest W, Zimmer H: Differential cytokine expression in myocytes and non-myocytes after myocardial infarction in rats. Mol Cell Biochem 2003;242:47-55.

$\checkmark 6$ Declayre C, Swynghedauw B: Molecular mechanisms of myocardial remodeling: the role of aldosterone. J Mol Cell Cardiol 2002; 34:1577-1584.

7 Rouleau JL: The neurohumoral hypothesis and the treatment of heart failure. Can J Cardiol 1996;12(suppl F):3F-8F.

$>8$ Weber KT, Sun Y, Guarda E: Structural remodeling in hypertensive heart disease and the role of hormones. Hypertension 1994;23: 869-877.

$>9$ Swynghedauw B: Molecular mechanisms of myocardial remodeling. Physiol Rev 1999; 79:215-262.

$\checkmark 10$ Cohn JN, Ferrari R, Sharpe N: Cardiac remodeling - concepts and clinical implications: a consensus paper from an international forum on cardiac remodeling. J Am Coll Cardiol 2000;35:569-582.

-11 Pfeffer MA, Braunwald E: Ventricular remodeling after myocardial infarction: experimental observations and clinical implications. Circulation 1990;81:1161-1172.

12 Bayer AL, Heidkamp MC, Patel N, Porter M, Engman S, Samarel AM: Alterations in protein kinase $\mathrm{C}$ isoenzyme expression and autophosphorylation during the progression of pressure overload-induced left ventricular hypertrophy. Mol Cell Biochem 2003;242: 145-152.

-13 Kiss E, Ball NR, Kranias EG, Walsh RA: Differential changes in cardiac phospholamban and sarcoplasmic reticular $\mathrm{Ca}^{2+}$-ATPase protein levels: effects on $\mathrm{Ca}^{2+}$ transport and mechanics in compensated pressure-overload hypertrophy and congestive heart failure. Circ Res 1995;77:759-764.
14 Arai M, Suzuki T, Nagai R: Sarcoplasmic reticulum genes are upregulated in mild cardiac hypertrophy but downregulated in severe cardiac hypertrophy induced by pressure overload. J Mol Cell Cardiol 1996;28: 1583-1590.

15 Hisamatsu Y, Ohkusa T, Kihara Y, Inolo M, Ueyama T, Yano M, Sasayama S, Tatsuzuki $\mathrm{M}$ : Early changes in the functions of cardiac sarcoplasmic reticulum in volume-overloaded cardiac hypertrophy in rats. J Mol Cell Cardiol 1997;29:1097-1109.

16 Wang X, Ren B, Liu S, Sentex E, Tappia PS, Dhalla NS: Characterization of cardiac hypertrophy and heart failure due to volume overload in the rat. J Appl Physiol 2003;94: $752-763$.

17 Sentex E, Wang X, Liu X, Lukas A, Dhalla NS: Expression of protein kinase $\mathrm{C}$ isoforms in cardiac hypertrophy and heart failure due to volume overload. Can J Physiol Pharmacol 2006:84:227-238.

18 Hutchins GM, Bulkley EH: Infarct expansion versus extension: two different complications of acute myocardial infarction. Am J Cardiol 1978;41:1127-1132.

19 Weber KT: Cardiac interstitium in health and disease: the fibrillar collagen matrix. J Am Coll Cardiol 1989;13:1637-1652.

20 Sabbah HN, Goldstein S: Ventricular remodeling: consequence and therapy. Eur Heart J 1993;14:24-29.

21 Weber KT, Brill CG: Pathological hypertrophy and cardiac interstitium: fibrosis and renin-angiotensin-aldosterone system. Circulation 1991;83:1849-1865.

22 Ju H, Zhaoe S, Jassal DV, Dixon IMC: Effect of $\mathrm{AT}_{1}$ receptor blockade on cardiac collagen remodeling after myocardial infarction. Cardiovasc Res 1997;35:223-232.

23 Briest W, Holzl A, Rabler B, Deten A, Baba HA, Zimmer H: Significance of matrix metalloproteinases in norepinephrine-induced remodeling of rat hearts. Cardiovasc Res 2003;57:379-387.

24 Weber KT, Clark WA, Janicki JS, Shroff SG: Physiologic versus pathologic hypertrophy and the pressure-overloaded myocardium. J Cardiovasc Pharmacol 1987;10(suppl):S37S49.

25 Zannad F, Radauceanu A: Effect of MR blockade on collagen formation and cardiovascular disease with a specific emphasis on heart failure. Heart Fail Rev 2005;10:71-78.

26 Liu YH, Yang XP, Sharov VG, Nass O, Sabbah HN, Peterson E, Carretero OA: Effects of angiotensin converting enzyme inhibitors and angiotensin II typel-receptor antagonists in rats with heart failure. J Clin Invest 1997;26:101-111.

27 Weber KT: Fibrosis in hypertensive heart disease: focus on cardiac fibroblasts. J Hypertens 2004;22:47-50.
28 Dhalla NS, Wang X, Beamish RE: Intracellular calcium handling in normal and failing hearts. Exp Clin Cardiol 1996;1:7-20.

29 Davies CH, Harding SE, Poole-Wilson PA: Cellular mechanisms of contractile dysfunction in human heart failure. Eur Heart J 1996;17:189-198.

30 Palermo J, Gulick J, Colbert M, Fewell J, Robbins J: Transgenic remodeling of the contractile apparatus in the mammalian heart. Circ Res 1996;78:504-509.

31 Dhalla NS, Shao Q, Panagia V: Remodeling of cardiac membranes during the development of congestive heart failure. Heart Fail Rev 1998;2:261-272.

32 Morgan JP, Erny RE, Allen PD, Grossman W, Gwathmey JK: Abnormal intracellular calcium handling, a major cause of systolic and diastolic dysfunction in ventricular myocardium from patients with heart failure. Circulation 1990;81(suppl):III21-III32.

33 Dhalla NS, Dixon IMC, Beamish RE: Biochemical basis of heart function and contractile failure. J Appl Cardiol 1991;6:7-30.

34 Schwinger RH, Bundgaard H, Muller-Ehmsen J, Kjeldsen K: The Na, K-ATPase in the failing human heart. Cardiovasc Res 2003; 57:913-920.

-35 Horisberger JD, Lemas V, Kraehenbuhl JP, Rossier BC: Structure-function relationship of Na,K-ATPase. Annu Rev Physiol 1991;53: 565-584.

-36 Charlemagne D, Orlowski J, Oliviero P, Rannou F, Saint Beuve C, Swynghedauw B, Lane LK: Alteration of $\mathrm{Na}, \mathrm{K}$-ATPase subunit mRNA and protein levels in hypertrophied rat heart. J Biol Chem 1994;269:1541-1547.

37 Dixon IMC, Hata T, Dhalla NS: Sarcolemmal $\mathrm{Na}^{+}-\mathrm{K}^{+}$-ATPase activity in congestive heart failure due to myocardial infarction. Am J Physiol Cell Physiol 1992;262:C664-C671.

38 Semb SO, Lunde PK, Holt E, Tonnessen T, Christensen G, Sejersted OM: Reduced myocardial $\mathrm{Na}^{+}, \mathrm{K}^{+}$-pump capacity in congestive heart failure following myocardial infarction in rats. J Mol Cell Cardiol 1998;30:13111328.

-39 Book CB, Moore RL, Semanchik A, Ng Y: Cardiac hypertrophy alters expression of $\mathrm{Na}^{+}, \mathrm{K}^{+}$-ATPase subunit isoforms at mRNA and protein levels in rat myocardium. J Mol Cell Cardiol 1994;26:591-600.

40 Kato K, Lukas A, Chapman DC, Dhalla NS: Changes in the expression of cardiac $\mathrm{Na}^{+}-\mathrm{K}^{+}$ ATPase subunits in the UM-X7.1 cardiomyopathic hamster. Life Sci 2000;67:1175-1183.

41 Shao Q, Ren B, Elimban V, Tappia PS, Takeda N, Dhalla NS: Modification of sarcolemmal $\mathrm{Na}^{+}-\mathrm{K}^{+}$ATPase and $\mathrm{Na}^{+} / \mathrm{Ca}^{2+}$ exchanger expression in heart failure by blockade of renin-angiotensin system. Am J Physiol Heart Circ Physiol 2005;288:H2637-2646. 
-42 Ren B, Shao Q, Ganguly PK, Tappia PS, Takeda N, Dhalla NS: Influence of long-term treatment of imidapril on mortality, cardiac function, and gene expression in congestive heart failure due to myocardial infarction. Can J Physiol Pharmacol 2004;82:11181127.

-43 Nicoll DA, Longory S, Philipson KD: Molecular cloning and functional expression of the cardiac sarcolemmal $\mathrm{Na}^{+}-\mathrm{Ca}^{2+}$ exchanger. Science 1990;250:562-565.

-44 Studer R, Reinecke H, Bilger J, Eschenhagen T, Bohm M, Hasenfuss G, Just H, Holtz J, Drexler H: Gene expression of the cardiac $\mathrm{Na}^{+}-\mathrm{Ca}^{2+}$ exchanger in end-stage human heart failure. Circ Res 1994;75:443-453.

-45 Hasenfuss G, Schillinger W, Lenhart SE, Preuss M, Pieske B, Maier LS, Prestle J, Minami K, Just $\mathrm{H}$ : Relationship between $\mathrm{Na}^{+}$$\mathrm{Ca}^{2+}$-exchanger protein levels and diastolic function of failing human myocardium. Circulation 1999;99:641-648.

46 Dixon IMC, Hata T, Dhalla NS: Sarcolemmal calcium transport in congestive heart failure due to myocardial infarction in rats. Am J Physiol Heart Circ Physiol 1992;262:H1387H1394.

-47 Schillinger W, Schneider H, Minami K, Ferrari R, Hasenfuss G: Importance of sympathetic activation for the expression of $\mathrm{Na}^{+}-$ $\mathrm{Ca}^{2+}$ exchanger in end-stage failing human myocardium. Eur Heart J 2002;23:11181124.

-48 Reinecke H, Studer R, Vetter R, Holtz J, Drexler $\mathrm{H}$ : Cardiac $\mathrm{Na}^{+} / \mathrm{Ca}^{2+}$ exchange activity in patients with end-stage heart failure. Cardiovasc Res 1996;31:48-54.

49 Komuro I, Kurabayashi M, Shibazaki Y, Takaku F, Yazaki Y: Molecular cloning and characterization of a $\mathrm{Ca}^{2+}+\mathrm{Mg}^{2+}$-dependent adenosine triphosphatase from rat cardiac sarcoplasmic reticulum. J Clin Invest 1989;83:1102-1108.

-50 Muliere LA, Hasenfuss G, Leavitt B, Allen PD, Alpert NR: Altered myocardial forcefrequency relation in human heart failure. Circulation 1992;85:1743-1750.

-51 Mercadier JJ, Lompre AM, Duc P, Boheler KR, Fraysse JB, Wisenewsky C, Allen PD, Komajda M, Schwartz K: Altered sarcoplasmic reticulum $\mathrm{Ca}^{2+}$-ATPase gene expression in the human ventricle during end-stage heart failure. J Clin Invest 1990;85:305-309.

52 Brillantes AM, Allen P, Takahashi T, Izumo S, Marks AR: Differences in cardiac calcium release channel (ryanodine receptor) expression in myocardium from patients with endstage heart failure caused by ischemic versus dilated cardiomyopathy. Circ Res 1992;71: 18-26.

-53 Arai M, Alpert NR, MacLennan DH, Barton $\mathrm{P}$, Periasamy M: Alterations in sarcoplasmic reticulum gene expression in human heart failure: a possible mechanism for alterations in systolic and diastolic properties of the failing myocardium. Circ Res 1993;72:463469.
54 Schwinger RHG, Bohm M, Schmidt U, Karczewski P, Bavendiek U, Flesch M, Krause E, Erdmann E: Unchanged protein levels of SERCA II and phospholamban but reduced $\mathrm{Ca}^{2+}$ uptake and $\mathrm{Ca}^{2+}$ ATPase activity of cardiac sarcoplasmic reticulum from dilated cardiomyopathy patients compared with patients with nonfailing hearts. Circulation 1995;92:3320-3228.

55 Meyer M, Schilinger W, Pieske B, Holubarsch C, Heilmann C, Posival H, Kuwajima G, Mikoshiba K, Just J, Hasenfuss G: Alterations of sarcoplasmic reticulum proteins in failing human dilated cardiomyopathy. Circulation 1995;92:778-784.

56 Toffolo RL, Ianuzzo CD: Myofibrillar adaptations during cardiac hypertrophy. Mol Cell Biochem 1994;131:141-149.

57 Wang J, Liu X, Ren B, Rupp H, Takeda N, Dhalla NS: Modification of myosin gene expression by imidapril in failing heart due to myocardial infarction. J Mol Cell Cardiol 2002;34:847-857.

58 Movsesian MA, Schwinger RHG: Calcium sequestration by the sarcoplasmic reticulum in heart failure. Cardiovasc Res 1998;37: 352-359.

59 Igarashi-Saito K, Tsutsui H, Yamamoto S, Takahashi M, Kinugawa S, Tagawa H, Usui M, Yamamoto M, Egashira K, Takeshita A: Role of SR $\mathrm{Ca}^{2+}$ ATPase in contractile dysfunction of myocytes in tachycardia-induced heart failure. Am J Physiol Heart Circ Physiol 1998;275:H31-H40.

60 Hisamatsu Y, Ohkusa T, Kihara Y, Inoko M, Ueyama T, Yano M, Sasayama S, Matsuzaki $\mathrm{M}$ : Early changes in the function of cardiac sarcoplasmic reticulum in volume-overloaded cardiac hypertrophy in rats. J Mol Cell Cardiol 1997;29:1097-1109.

61 Shao Q, Ren B, Saini HK, Netticadan T, Takeda N, Dhalla NS: Sarcoplasmic reticulum $\mathrm{Ca}^{2+}$ transport and gene expression in congestive heart failure are modified by imidapril treatment. Am J Physiol Heart Circ Physiol 2005;288:H1674-H1682.

62 Flesch M, Schiffer F, Zolk O, Pinto Y, Stasch JP, Knorr A, Ettelbruck S, Bohm M: Angiotensin receptor antagonism and angiotensin converting enzyme inhibition improve diastolic dysfunction and $\mathrm{Ca}^{2+}$ ATPase expression in the sarcoplasmic reticulum in hypertensive cardiomyopathy. J Hypertens 1997; 15:1001-1009.

63 Sasaki T, Inui M, Kimura Y, Kuzuya T, Tada $\mathrm{M}$ : Molecular mechanism of regulation of $\mathrm{Ca}^{2+}$ pump ATPase by phospholamban in cardiac sarcoplasmic reticulum: effects of synthetic phospholamban peptides on $\mathrm{Ca}^{2+}$ pump ATPase. J Biol Chem 1992;267:16741679.

64 Luo W, Gurpp IL, Harrer J, Ponniah S, Grupp G, Dufy JJ, Doetschman T, Kranias EG: Targeted ablation of the phospholamban gene is associated with markedly enhanced myocardial contractility and loss of $\beta$-agonist stimulation. Circ Res 1994;75:401-409.
65 Holmberg SR, Williams AJ: The calcium-release channel from cardiac sarcoplasmic reticulum: function in the failing and acutely ischemic heart. Basic Res Cardiol 1992; 87(suppl 1):255-268.

66 Cory CR, McCutcheon LJ, O’Grady M, Pang AW, Geiger JD, O’Brien PJ: Compensatory downregulation of myocardial Ca channel in SR from dogs with heart failure. Am J Physiol Heart Circ Physiol 1993;33:H926-H937.

67 Morano I, Hadicke K, Haase H, Bohm M, Erdmann E, Schaub MC: Changes in essential myosin light chain isoform expression provide a molecular basis for isometric force regulation in the failing human heart. J Mol Cell Cardiol 1997;29:1177-1187.

68 Anderson PAW, Malouf NN, Oakeley AE, Pagani ED, Allen PD: Troponin T isoform expression in the normal and failing human left ventricle: a correlation with myofibrillar ATPase activity. Basic Res Cardiol 1992; 87(suppl 1):117-127.

69 Solaro RJ, Powers FM, Gao L, Gwathmey JK Control of myofilament activation in heart failure. Circulation 1993;87(suppl VII):3843.

70 Pagani ED, Alousi AA, Grant AM, Older TM, Dziuban SW, Allen PD: Changes in myofibrillar content and Mg-ATPase activity in ventricular tissues from patients with heart failure caused by coronary artery disease, cardiomyopathy, or mitral valve insufficiency. Circ Res 1988;63:380-385.

71 Alousi AA, Grant AM, Etzler LR, Cofer BR, Van der Bel-Kahn J, Melvin D: Reduced cardiac myofibrillar Mg-ATPase activity without changes in myosin isozymes in patients with end-stage heart failure. Mol Cell Biochem 1990;96:79-88.

72 Buttrick P, Malhotra A, Factor S, Greene D, Scheuer J: Effect of chronic dobutamine administration on hearts of normal and hypertensive rats. Circ Res 1988;63:173-181.

73 Izumo S, Lompre A, Matsuoka R, Koren G, Schwartz K, Nadal-Ginard B, Mahdavi V: Myosin heavy chain messenger RNA and protein isoform transitions during cardiac hypertrophy. J Clin Invest 1987;79:970-977.

74 Eble DM, Walker JD, Mukherjee R, Samarel AM, Spinale FG: Myosin heavy chain synthesis is increased in a rabbit model of heart failure. Am J Physiol Heart Circ Physiol 1997;272:H969-H978.

75 Imamura T, McDermott PJ, Kent RL, Nagatsu M, Cooper G, Carabello BA: Acute changes in myosin heavy chain synthesis rate in pressure versus volume overload. Circ Res 1994;75:418-425.

76 Wang J, Guo X, Dhalla NS: Modification of myosin protein and gene expression in failing hearts due to myocardial infarction by enalapril or losartan. Biochim Biophys Acta 2004;1690:177-184. 
-77 Guo X, Saini HK, Wang J, Gupta SK, Goyal RK, Dhalla NS: Prevention of remodeling in congestive heart failure due to myocardial infarction by blockade of the renin-angiotensin system. Expert Rev Cardiovasc Ther 2005;3:717-732.

78 Feldman AM: Modulation of adrenergic receptors and G-transduction proteins in failing human ventricular myocardium. Circulation 1993;87(suppl IV):IV27-IV34.

-79 Bohm M, Diett F, Feiler G, Kemkes B, Erdmann E: $\alpha$-Adrenoceptors and $\alpha$-adrenoceptor-mediated positive inotropic effects in failing human myocardium. J Cardiovasc Pharmacol 1988;12:357-364.

$\checkmark 80$ Bristow MR, Hershberger RE, Port JD, Rasmussen R: $\beta_{1}$ and $\beta_{2}$-adrenergic receptor mediated adenylate cyclase stimulation in nonfailing and failing human ventricular myocardium. Mol Pharmacol 1989;35:295303.

-81 Fowler MB, Laser JA, Hopkins GL, Minobe W, Bristow MR: Assessment of the $\beta$-adrenergic receptor pathway in the intact failing human heart: progressive receptor downregulation and subsensitivity to agonist response. Circulation 1986;74:1290-1302.

82 Hadcock JR, Malbon CC: Down-regulation of $\beta$-adrenergic receptors: agonist-induced reduction in mRNA levels. Proc Natl Acad Sci USA 1988;85:5021-5025.

- 83 Eschenhagen T, Mende U, Diederich M, Nose M, Schmitz, Scholz H, Scholte am Esch J, Warnholz A, Schafer H: Long term $\beta$-adrenoceptor-mediated up-regulation of $\mathrm{G}_{\mathrm{i}} \alpha$ and $G_{0} \alpha$ mRNA level and pertussis toxinsensitive guanine nucleotide-binding proteins in rat heart. Mol Pharmacol 1992;42: 773-783.

84 Lai L, Raju VS, Delehanty JM, Yatani A, Liang C: Altered sarcoplasmic reticulum $\mathrm{Ca}^{2+}$ ATPase gene expression in congestive heart failure: effect of chronic norepinephrine infusion. J Mol Cell Cardiol 1998;30:175-185.

85 Ju H, Scammell-La Fleur T, Dixon IMC: Altered mRNA abundance of calcium transport genes in cardiac myocytes induced by angiotensin II. J Mol Cell Cardiol 1996;28: 1119-1128.
86 Rouet-Benzineb P, Gontero B, Dreyfus P, Lafuma C: Angiotensin II induces nuclear factor- $\mathrm{\kappa B}$ activation in cultured neonatal rat cardiomyocytes through protein kinase $\mathrm{C}$ signaling pathway. J Mol Cell Cardiol 2000; 32:1767-1778.

87 Jugdutt BI, Schwarz-Michorowski BL, Khan MI: Effect of long-term captopril therapy on left ventricular remodeling and function during healing of canine myocardial infarction. J Am Coll Cardiol 1992;19:713-721.

88 McDonald KM, Chu C, Francis GS, Carlyle W, Judd DL, Hauer K, Hartman M, Cohn JN: Effect of delayed intervention with ACE-inhibitor therapy on myocyte hypertrophy and growth of the cardiac interstitium in the rat model myocardial infarction. J Mol Cell Cardiol 1997;29:3203-3210.

89 Dixon IMC, Ju H, Jassal DS, Peterson DJ: Effect of ramipril and losartan on collagen expression in right and left heart after myocardial infarction. Mol Cell Biochem 1996;165: 31-45.

90 Jessup M, Brozena S: Heart failure. N Engl J Med 2003;348:2001-2018.

91 Fedak PWM, Verma S, Weisel RD, Li RK: Cardiac remodeling and failure from molecules to man (part 1). Cardiovasc Physiol 2005;12:1-11.

92 Baig MK, Mahon N, McKenna WJ, Caforio ALP, Bonow RD, Francis GS, Gheorghiade M: The pathophysiology of advanced heart failure. Am Heart J 1998;135:S216-S230.

93 Dhalla NS, Dent MR, Tappia PS, Sethi R, Barta J, Goyal RK: Subcellular remodeling as a viable target for the treatment of congestive heart failure. J Cardiovasc Pharmacol Ther 2006;11:31-45.

\$94 Boheler KR, Volkova M, Morrell C, Garg R, Zhu Y, Margulies K, Seymour AM, Lakatta EG: Sex- and age-dependent human transcriptome variability: implications for chronic heart failure. Proc Natl Acad Sci USA 2003;100:2754-2759.

95 Tabibiazar R, Wagner RA, Liao A, Quertermous T: Transcriptional profiling of the heart reveals chamber-specific gene expression patterns. Circ Res 2003;93:1193-1201.
96 Laframboise WR, Bombach KL, Dhir RJ, Muka N, Cullen RF, Pogozelski AR, Turk D, Geouge JD, Guthrie RD, Magovern JR: Molecular dynamics of the compensatory response to myocardial infarct. J Mol Cell Cardiol 2005;38:547-550.

-97 Sharma UC, Pokharel S, Evelo CR, Maessen JG: A systematic review of large scale and heterogeneous gene array data in heart failure. J Mol Cell Cardiol 2005;38:425-432.

$\checkmark 98$ Liew CC: Expressed genome molecular signatures of heart failure. Clin Chem Lab Med 2005;43:462-469.

99 Steenman M, Lamirault G, Le Meur N, Leger JJ: Gene expression profiling in human cardiovascular disease. Clin Chem Lab Med 2005;43:696-701.

100 Houser SR, Piacentino V 3rd, Weisser J: Abnormalities of calcium cycling in the hypertrophied and failing heart. J Mol Cell Cardiol 2000;32:1595-1607.

101 Bing OHL, Conrad CH, Boluyt MO, Robinson KG, Brooks WW: Studies of prevention, treatment and mechanisms of heart failure in the aging spontaneously hypertensive rat. Heart Fail Rev 2002;7:71-88.

102 Pacher P, Mabley JG, Liaudet L, Evgenov OV, Marton A, Hasko G, Kollai M, Szabo C: Left ventricular pressure-volume relationship in a rat model of advanced aging-associated heart failure. Am J Physiol Heart Circ Physiol 2004;287:H2132-H2137.

103 Mengi SR, Dhalla NS: Carnitine palmitoyltransferase-I, a new target for the treatment of heart failure: perspectives on a shift in myocardial metabolism as a therapeutic intervention. Am J Cardiovasc Drugs 2004;4: 201-209.

104 Yoshida $\mathrm{H}$, Karmazyn $\mathrm{M}: \mathrm{Na}^{+} / \mathrm{H}^{+}$exchange inhibition attenuates hypertrophy and heart failure in 1-wk postinfarction rat myocardium. Am J Physiol Heart Circ Physiol 2000;278:H300-H304.

105 Sethi R, Shao Q, Ren B, Saini HK, Takeda N, Dhalla NS: Changes in beta-adrenoceptors in heart failure due to myocardial infarction are attenuated by blockade of renin-angiotensin system. Mol Cell Biochem 2004;263:11-20. 